\title{
Investigating the effect of customers' education level on loyalty and trust (Case study: Alborz Province Export Bank)
}

\section{Investigar o efeito do nível de educação dos clientes na lealdade e confiança (estudo de caso: Banco de exportação da província de}

\section{Alborz)}

\section{Shahla Sohrabi}

Department of Management, West Tehran Branch, Islamic Azad University, Tehran, Iran ORCID: 0000-0002-0840-8823

Pouria Rahimi

Department of Management, Qods Branch, Islamic Azad University, Tehran, Iran ORCID: 0000-0002-2928-0742

Received 09-08-20 Revised 10-10-20

* Correspondence

Email: modiran77@gmail.com
Accepted 12-12-20 On line 03-15-21

Citation:
Shahla Sohrabi, Pouria Rahimi (2020). The effect of customer participation on customer loyalty with the mediating role of trust (Case study: Bank Saderat of Alborz Province). Propósitos y Representaciones, 9 (SPE3), e1150. Doi: http://dx.doi.org/10.20511/pyr2021.v9nSPE3.1150 


\begin{abstract}
The purpose of this study is to determine the effect of customer participation on customer loyalty with the mediating role of trust by considering the effect of literacy level. This research is descriptive-survey in terms of data collection method and applied in terms of purpose. The statistical population of the present study included all customers with different levels of literacy in Bank Saderat. Using Cochran's formula, the sample size required for the study was 196 people. The collection tool in this study was a questionnaire of Chen et al. The reliability of these questionnaires was confirmed using Cronbach's alpha coefficient. Amos23 software was used to analyze the collected data. The results showed that customer participation has a significant impact on customer loyalty. In addition, as the level of literacy of customers increases, their level of cooperation and trust increases or decreases. Trust also plays a mediating role in customer engagement, which affects customer loyalty
\end{abstract}

Keywords: Customer Participation, Customer Loyalty, Trust, Satisfaction, education level

\title{
Resumen
}

O objetivo deste estudo é determinar o efeito da participação do cliente na lealdade do cliente com o papel mediador da confiança, considerando o efeito do nível de alfabetização. Esta pesquisa é descritiva-survey em termos de método de coleta de dados e aplicada em termos de finalidade. A população estatística do presente estudo incluiu todos os clientes com diferentes níveis de alfabetização no Banco Saderat. Usando a fórmula de Cochran, o tamanho da amostra necessário para o estudo foi de 196 pessoas. O instrumento de coleta neste estudo foi um questionário de Chen et al. A confiabilidade desses questionários foi confirmada pelo coeficiente alfa de Cronbach. O software Amos23 foi utilizado para analisar os dados coletados. Os resultados mostraram que a participação do cliente tem um impacto significativo na fidelização do cliente. Além disso, à medida que o nível de alfabetização dos clientes aumenta, seu nível de cooperação e confiança aumenta ou diminui. A confiança também desempenha um papel mediador no envolvimento do cliente, o que afeta a fidelidade do cliente

Palabras clave: participación Del cliente, lealtad Del cliente, confianza, satisfacción, nível de educação

\section{Introduction}

Increasing competition in today's markets has made companies pay more attention to retaining current customers and trying to attract customers (Chen et al., 2016). Today's business enterprises consider themselves obliged to provide the best service or products to their customers, and the goal of organizations is to develop long-term relationships between the company and customers. Therefore, the most important concern of today's organizations can be considered customer retention. In this regard, the development of the concept of customer loyalty has attracted the interest of many marketing activists and academic researchers. So many research has been conducted on the factors that lead to customer loyalty (Stan et 1., 2013). In order to improve their competitive advantage, service companies have put paying more attention to customers on their agenda (Hayes, 2008). Because customers are the driving force behind profitable growth, customer loyalty can lead to profitability. Therefore, it is essential for service companies to maintain customer loyalty that leads to long-term profitability of business organizations (Tseng, 2007). Loyal customers are unlikely to turn to a competitor just because of the price, and they make even more purchases than disloyal customers (Ou et al., 2011) do. On the other hand, marketing literature attaches great importance to the interaction between customers and the company (Auh et al., 2007; Yi et al., 2011) Because customer participation increases loyalty and helps, build a profitable relationship with 
customers, which leads to their retention (Bendapudi \& Leone, 2003; Paine \&Organ, 2000). Recent research has significantly focused on the role of customer participation in service marketing literature (Revilla-Camacho et al., 2015). These interactions share information and better identify customer and company needs (Homburg et al., 2007; Sharma et al., 2014).

Based on that logic, there is an assumption that the higher degree of customer engagement into value creation is the greater trust between customers and company exists. It can be said that the relationship between customer participation in value creation and trust is a mutual issue. The relationship between satisfaction and trust has been extensively studied in relationship marketing literature (Sashi, 2012). Satisfaction is the default of trust in providing services. On the other hand, theoretical approaches to relationship marketing have made it possible for us to claim the effect of trust on customer satisfaction, and therefore the relationship between structures can be mutually analyzed (Selnes, 1998). According to Raja et al. (2008), both structures can be considered as a mediating factor between customer participation in value creation and customer loyalty. Trust and satisfaction in relationship marketing literature are considered as the main factors of long-term relationships; the main activity of marketing professionals these days is to show the impact of creating customer value on customer satisfaction, trust, and relationship strength and customer loyalty. Customer participation of service companies increases the value, satisfaction and trust of customers, which leads to a stronger relationship between the company and customers and customer loyalty. The authors also found that the relationship between customer participation in value creation and relationship strength is negative, if customers do not feel satisfied and do not trust the company (Rajah et al., 2008).

Therefore, the purpose of this study is to determine the relationship between customer participation on customer loyalty and the mediating role of trust in Bank Saderat of Alborz Province.

\section{Theoretical Foundations}

\section{Customer participation}

In general, customer participation refers to the role of customer in the service production process or tangible goods. The nature of services makes customers more willing to participate in the production and delivery of them compared to tangible goods. Customer participation is defined in four dimensions: Searching for information means willingness of customers to obtain more information on the nature and how to use services and how to provide services, etc. Sharing information means exchanging information between customers and employees about how to provide services, responsible behavior, commitment and responsibility of customers for the services received and the performance of the customer's duties, individual interactions, respectability of customers towards the employees and establishing friendly relations with them (Manoj \& Sunil, 2011). Customers are the complementary part of the service delivery system and a tool for measuring the desired service results by the company (Ndubisi, 2007).

\section{Loyalty}

The high costs of attracting customers compared to the lower costs of providing services to existing customers and thus increasing profitability is an important reason to increase attention to customer retention among companies. Customer retention behavior in marketing literature is one of the main concepts related to consumer markets. Researchers believe that customer retention is necessary for businesses that want stability and sustainability. Today, it has been explained that customer loyalty is more important than customer satisfaction in a company's business success (Ou et al., 2011). Loyal customers provide the company with amazing marketing power through word of mouth. Loyalty is defined as a strong commitment in customers to make exchanges with a particular organization and buy goods and services continuously and repeatedly (Chuah et al., 2014). A number of authors emphasize the positive and existing relationship between customer loyalty and business performance. Researchers believe that loyal customers not only increase the business value but also enable the business to spend less on attracting new customers (Meng et al., 2011).

\section{Satisfaction}


Customer satisfaction has a positive effect on an organization's profitability. Research shows that satisfied customers share their shopping experience with other people (perhaps 5-6 people), while dissatisfied customers share their experience about a product or service with more than 10 people (Rigatti-Luchini \& Mason, 2010). Therefore, customer satisfaction is critical to the survival and success of an organization (Hosseini \& Hosseini, 2013).

Different definitions have been proposed by marketing theorists regarding the concept of customer satisfaction. Cutler defines customer satisfaction as the degree to which actual performance of a company meets customer expectations. It refers to customers' emotional response to the use of products and services under certain conditions, which is created in the process of using services. Research shows that customer satisfaction leads to repetition of purchases, word of mouth advertising and customer citizenship behavior (Hosseinpour \& Hassan Reza, 2011). Customer satisfaction has been defined in different ways. Because customer satisfaction is an abstract and ambiguous concept, there are several definitions in different industries and service sectors. Here is one of the definitions that is widely used: Satisfaction is a judgmental assessment before deciding on a particular exchange that can be directly interpreted as a general, well-defined feeling as a function of perceived quality (Yen et al., 2004).

\section{Trust}

Doney and Cannon (1997) define trust as the perception of credibility and benevolence about a goal. They define trust as the perception of the confidence in exchange, the reliability and integrity of the partner, and they believe that trust is the basis of a relationship commitment. Trust is achieved when one party is truly confident in the other (Chau \& Ngai, 2010). Confidence builds the belief that the other party is trustworthy and confident, and will lead to strong, honest, fair, and helpful cooperation. Relationship marketing is based on trust. The structure of trust is specifically concerned with creating interest in relationship marketing. Numerous researchers have cited trust as a key factor in creating and developing successful relationships with customers and customer loyalty (Morgan \& Hunt, 1994).

Vidoto et al. (2012) examined the dimensions of trustability in 36 students at the University of Padua, Italy. The results showed that the four dimensions of trust beliefs (competence, benevolence, explicitness and predictability) play an important role in judging trust. In other words, competence, honesty, and predictability play the most important role in positive judgment, and low honesty plays the most important role in negative judgment (Zeithaml et al., 1996).

\section{Background}

Table (1) show some of the research conducted on the subject of research.

Table 1. Some of the research conducted on the subject of research

\begin{tabular}{ccl}
\hline Researchers & Year & \multicolumn{1}{c}{ Results } \\
\hline Khabiri et al. & 2014 & $\begin{array}{l}\text { The results show that the four variables of trust, commitment, } \\
\text { communication and competence have a significant effect on } \\
\text { the quality of the relationship and the quality of the } \\
\text { relationship has a positive and significant effect on customer } \\
\text { participation in word of mouth among club customers } \\
\text { (Vidotto et al., 2012). } \\
\text { Customer participation in production has a positive effect on } \\
\text { customer loyalty, Employee-customer communication, } \\
\text { customer skills, emotional commitment, and interactive justice } \\
\text { increase customer participation in production (Rigatti-Luchini } \\
\text { \& Mason, 2010) } \\
\text { Customer participation consists of six dimensions: generous } \\
\text { participation, trusted participation, aspiring participation, } \\
\text { equitable participation, firm participation, truth-oriented }\end{array}$ \\
Hosseinpour et al. 2013
\end{tabular}


Babaei et al.

2015

Yen et al.

2004

Barry and Parasorman

Egan participation. Satisfaction was also measured by the ten dimensions of quality in the field of services (Khabiri \& Rezgar, 2014).

Customer participation has a significant effect on customer loyalty. Also, perceived value plays a mediating role in the effect of customer participation on customer loyalty (Hosseinpour \& Hassan Reza, 2011).

2016 The results showed that customer participation has a significant effect on customer loyalty. Perceived value also plays a mediating role in the effect of customer participation on customer loyalty (Chen et al., 2016).

Customer citizenship behavior and customer participation have a negative effect on customer's intention to leave (Camacho et al., 2015).

The participatory roles accepted by customers are effective in determining and delivering service and their pre-justified service experiences. Accordingly, people who have been more participated in the production and service delivery process blame themselves more on the failure of the service than on the organization and its employees (Hosseinpour \& Hassan Reza, 2011).

Trust is as the main factor in creating and developing a successful relationship with customer and customer loyalty (Morgan \& Hunt, 1994).

Creating the best value for customers while participating customers leads to customer retention and loyalty (Babaei et al., 2016).

\section{Conceptual framework of the research}

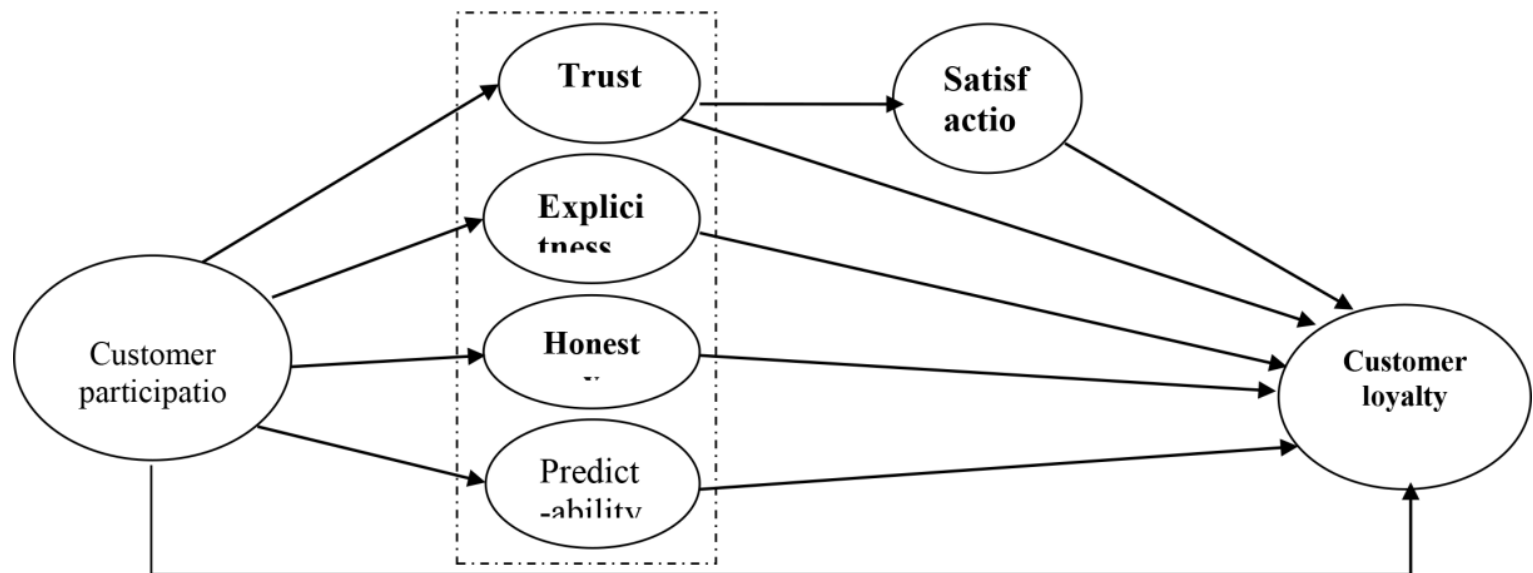

Figure 1. Conceptual model of the research (Chen et al., 2016)

\section{Hypotheses}

1. Customer participation affects customer loyalty.

2. Trust plays a mediating role in the effect of customer participation on customer loyalty.

3. Satisfaction plays a mediating role in the effect of trust on customer loyalty. loyalty.

4. Explicitness plays a mediating role in the effect of customer participation on customer

5. Honesty plays a mediating role in the effect of customer participation on customer loyalty.

6. Predictability plays a mediating role in the effect of customer participation on customer loyalty. 
The present study is applied in terms of purpose and descriptive-survey in terms of method. The statistical population of the present study includes customers of Alborz Province Bank Saderat. Cochran's formula was used to calculate the sample number. According to the Cochran's formula, in this study, the sample size is equal to 196 people. In this study, the non-random available sampling method was used. Library and field studies have been used to collect the required data. The collection tool in this study is a standard questionnaire. The first part of the questionnaire includes demographic variables (gender, age, marital status, level of education, work experience), and the second part contains 19 questions related to the research variables, which were prepared on a Likert scale. Cronbach's alpha was also used to estimate the reliability coefficient, which shows that all coefficients are above 0.7. In this study, AMOS23 software was used to analyze the data.

Table 2. Cronbach's alpha results

\begin{tabular}{cc}
\hline Variables & Cronbach's Alpha \\
\hline Customer participation & 0.827 \\
\hline Trust & 0.877 \\
\hline Honesty & 0.875 \\
\hline Explicitness & 0.821 \\
\hline Predictability & 0.824 \\
\hline Satisfaction & 0.819 \\
\hline Customer loyalty & 0.820 \\
\hline
\end{tabular}

\section{Data analysis}

Statistical descriptive and inferential discussions have been used to analyze the questionnaire. Descriptive statistics include frequency and mean tables, and at the inferential level, the structural equations modeling test, including confirmatory factor analysis and path analysis, has been used.

\section{Descriptive statistics: Description of demographic variables}

In the present study, 196 samples of customers of Alborz Bank Saderat were included, of which 147 were men and 49 were women. In addition, 32 people had diploma and under diploma, degrees and less than 19 people had associate degrees, 84 people had bachelor's degrees, 50 people had master's degrees and 11 people had Ph.D. degrees. Also, 11 people were 18 to 28 years old, 40 people were 29 to 38 years old, 71 people were 39 to 48 years old, 46 people were 49 to 58 years old and 28 people were over 59 years old.

\section{Description of variables:}


Table 3 shows the result of Kolmogorov-Smirnov normality Examination of data distribution.

Table 3. Description of the research variables

\begin{tabular}{cccc}
\hline Variables & Mean & Standard deviation & Significance \\
\hline Customer participation & 4.185 & 0.730 & 0.838 \\
\hline Honesty & 3.854 & 0.610 & 0.300 \\
\hline Explicitness & 3.841 & 0.630 & 0.191 \\
\hline Predictability & 3.245 & 0.579 & 0.221 \\
\hline Trust & 3.759 & 0.630 & 0.301 \\
\hline Satisfaction & 3.831 & 0.643 & 0.198 \\
\hline Customer loyalty & 3.278 & 0.593 & 0.221 \\
\hline Total 196 & & & \\
\hline
\end{tabular}

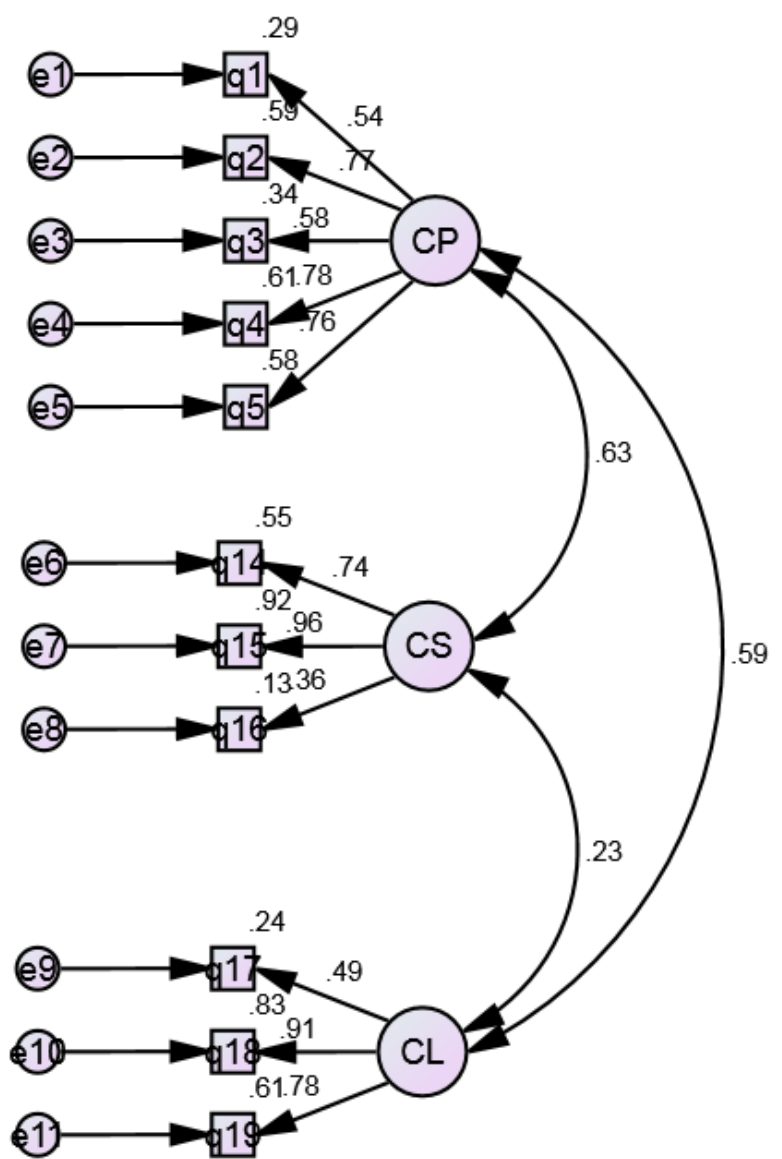

Figure 2. Research measurement model with factor loads

The status of the fit indicators for the conceptual model of the research is given in the following table. 
Table 4. Fit indicators of the measurement model

\begin{tabular}{|c|c|c|c|c|c|}
\hline Indicator & AGFI & GFI & CFI & NNFI & RMSEA \\
\hline $\begin{array}{c}\text { The } \\
\text { proposed } \\
\text { criterion }\end{array}$ & $<0.8$ & $<0.9$ & $<0.9$ & $<0.9$ & $<0.08$ \\
\hline $\begin{array}{c}\text { The reported } \\
\text { criterion }\end{array}$ & 0.912 & 0.925 & 0.911 & 0.981 & 0.06 \\
\hline
\end{tabular}

Based on the results of the research on the fit test of the model and the various fit indicators, the fit of the confidence model was at an acceptable level.

\section{Confidence measurement model}

To estimate the measurement model of the present study, the data collected using AMOS software were analyzed by confirmatory factor analysis, the findings of which are given in Figure 3 and Table 5 .

The status of the fit indicators for the conceptual model of the research is given in the following table.

Table 5. Fit indicators of the measurement model

\begin{tabular}{|c|c|c|c|c|c|}
\hline Indicator & AGFI & GFI & CFI & NNFI & RMSEA \\
\hline $\begin{array}{c}\text { The } \\
\text { proposed } \\
\text { criterion }\end{array}$ & $<0.8$ & $<0.9$ & $<0.9$ & $<0.9$ & $<0.08$ \\
\hline $\begin{array}{c}\text { The reported } \\
\text { criterion }\end{array}$ & 0.909 & 0.926 & 0.953 & 0.991 & 0.04 \\
\hline
\end{tabular}

Based on the results of the research on the fit test of the model and the various fit indicators, the fit of the confidence model was at an acceptable level.

\section{Fit of the structural model}

In the structural model, the relationships between the latent features are noteworthy. In fact, in the structural model, the relationships between the latent features that are extracted based on the theory are explained according to the data collected from the sample. In the structural model, the research hypotheses are tested using path analysis.

The fit of the present research model according to the data obtained from the results of Amos software is as follows:

Table 6. Fit indicators of the structural model

\begin{tabular}{|c|c|c|c|c|c|}
\hline Indicator & AGFI & GFI & CFI & NNFI & RMSEA \\
\hline $\begin{array}{c}\text { The } \\
\text { proposed } \\
\text { criterion }\end{array}$ & $<0.8$ & $<0.9$ & $<0.9$ & $<0.9$ & $<0.08$ \\
\hline $\begin{array}{c}\text { The reported } \\
\text { criterion }\end{array}$ & 0.95 & 0.91 & 0.97 & 0.90 & 0.003 \\
\hline
\end{tabular}

As shown in the diagram, all fit indicators of the model are in good condition. For example, the significance level of the chi square model is more than $5 \%$, indicating that the experimental data adequately support the conceptual model of the research. Also, the value of the mean square root of the estimation error is less than $10 \%$, and this indicator confirms the fit of the model as well. In order to test the research hypotheses, structural equations modeling (SEM) was used using the maximum likelihood estimation method in Amos software. During all stages of the analysis, the covariance matrix became the basis for the work. The following figure shows the structural relationships of the research model. 


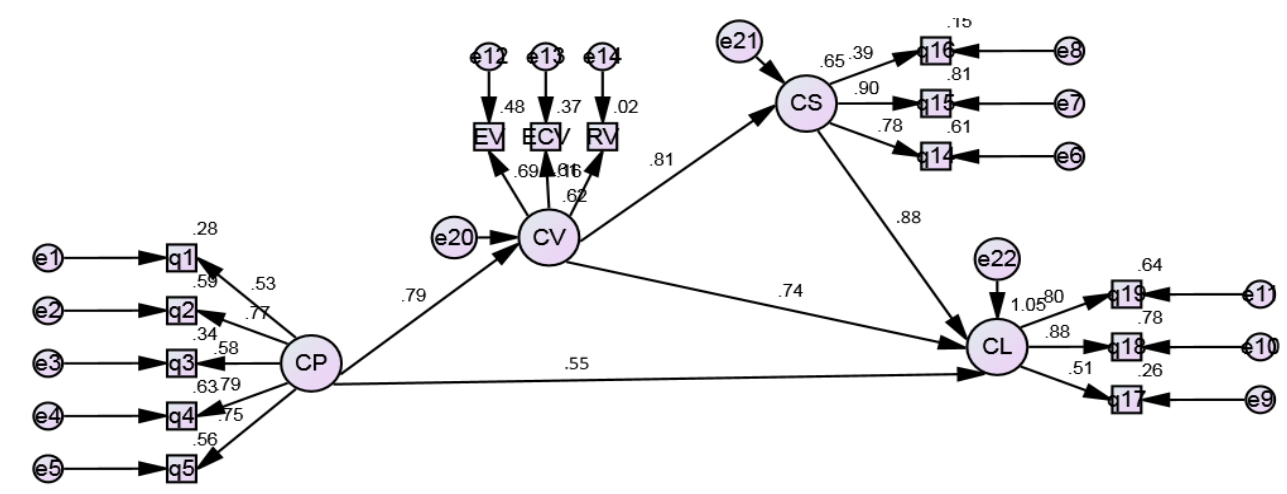

Figure 3. Structural model of the research with factor loads

\section{Hypothesis test}

Considering that in addition to examining and testing the goodness of fit of the research model and determining the variance rate expressed by independent variables of the research, another main goal of developing the structural model is to determine the significance of the path coefficients assumed in the conceptual model of the research in the form of the research hypotheses; therefore, in this section, the results of the research are described separately for each of the main research hypotheses:

Table 7. Hypothesis path coefficient

\begin{tabular}{|c|c|c|c|c|}
\hline Hypothesis & $\begin{array}{c}\text { Path } \\
\text { coefficient }\end{array}$ & $\begin{array}{c}\text { Critical } \\
\text { ratio }\end{array}$ & $\begin{array}{c}\text { Significance } \\
\text { level }\end{array}$ & $\begin{array}{c}\text { Result of } \\
\text { Hypothesis }\end{array}$ \\
\hline $\begin{array}{c}\text { Customer participation -> customer } \\
\text { loyalty }\end{array}$ & 0.55 & 4.537 & 0.000 & Confirmed \\
\hline $\begin{array}{c}\text { Customer participation -> trust -> } \\
\text { loyalty }\end{array}$ & 0.58 & - & 0.000 & Confirmed \\
\hline \begin{tabular}{c} 
trust -> satisfaction -> loyalty \\
\hline
\end{tabular} & 0.71 & - & 0.000 & Confirmed \\
\hline
\end{tabular}

Based on the test results, the research hypotheses and structural relationships between the variables show the research model. Based on this model, the first research hypothesis, which deals with the positive and significant effect of customer participation on loyalty, was confirmed according to the path coefficient of 0.55 and the critical ratio (4.537) at the 0.05 detection level. The second hypothesis examines the mediating role of trust in the effect of participation on customer loyalty, which was confirmed according to the change in the path coefficient from 0.55 to 0.58 at the 0.05 detection level. Accordingly, it is observed that the third hypothesis, which examines the mediating role of satisfaction in the effect of trust on customer loyalty, was confirmed according to the change in the path coefficient from 0.74 to 0.71 at the 0.05 detection level. 


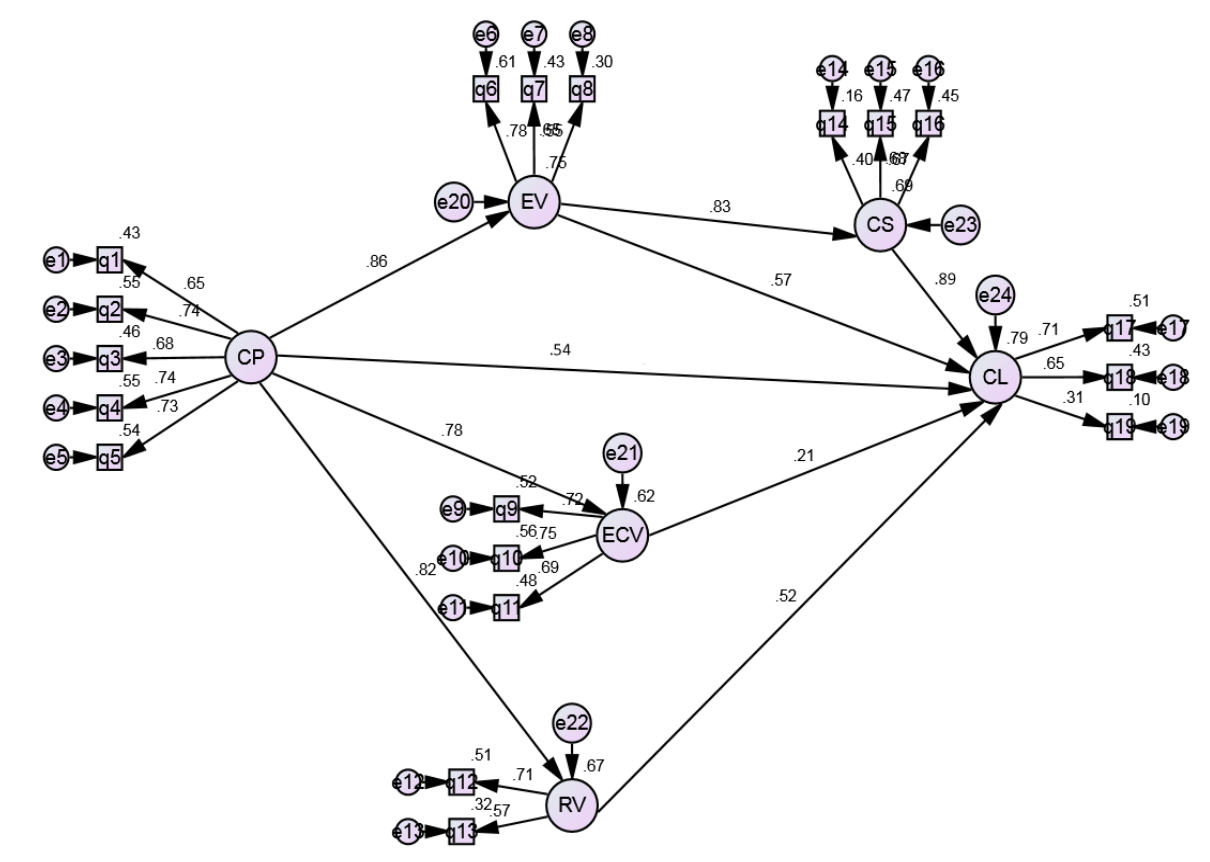

Figure 4. Structural model of the research with factor loads

Table 8. Hypothesis path coefficient

\begin{tabular}{|c|c|c|}
\hline Hypothesis & Path coefficient & $\begin{array}{c}\text { Result of } \\
\text { Hypothesis }\end{array}$ \\
\hline Customer participation -> honesty -> loyalty & 0.49 & Confirmed \\
\hline Customer participation -> explicitness -> loyalty & 0.16 & Confirmed \\
\hline Customer participation -> predictability -> loyalty & 0.42 & Confirmed \\
\hline
\end{tabular}

The fourth hypothesis examines the mediating role of honesty in the effect of participation on customer loyalty, which was confirmed according to the change in the path coefficient from 0.55 to 0.49 at the 0.05 detection level. The fifth hypothesis examines the mediating role of explicitness in the effect of participation on customer loyalty, which was confirmed according to the change in the path coefficient from 0.55 to 0.16 at the 0.05 detection level. The sixth hypothesis examines the mediating role of predictability in the effect of participation on customer loyalty, which was confirmed according to the change in the path coefficient from 0.55 to 0.42 at the 0.05 detection level.

\section{Discussion and Conclusion}

Today, customer loyalty is the key to business success. With increasing customer loyalty, market share and the profitability of the enterprise increase. Understanding the market by planning and adopting appropriate strategies to keep customers loyal and increase their loyalty rate creates longterm benefits for enterprises. The aim of this study was to investigate the effect of customer participation on customer loyalty with a mediating role of trust. All hypotheses of this study were tested and confirmed by structural equations modeling in Amos software. The results showed that customer participation has a significant effect on customer loyalty. This result is consistent with the research results of Hosseini et al. (2013); Chen et al. (2016); Kamacho et al. (2015) and Yen et al. (2004). The findings of this study could be useful for managers of public and private banks. Based on the research findings, it can be concluded that customers should understand that their participation leads to improving the quality, increasing trust, ease or speed in receiving services, and on the other hand, managers, by identifying the clients and giving them rewards, should create the necessary motivation to continue this collaboration and encourage other clients to change their behavior.

Given the effect that customer trust has on the effect between customer participation and loyalty, it is recommended that more attention be paid to the four dimensions of trust. If a privileged organization constantly improves its services and increases trust, it will survive in a highly 
competitive environment and can achieve its ultimate goal, which is customer satisfaction and ultimately customer loyalty. Therefore, it is important for managers to implement innovations that are not only favorable to customers but also economically viable and beneficial to the company and lead to loyalty. Giving the right information in marketing messages, catalogs and personal consultation of employees with customers and treatment with honesty and explicitness will increase trust of the bank's customers.

Based on the research findings, it is suggested that banks use customer participation in service delivery, according to the values that it creates for customers and subsequently increases the level of customer attitudinal loyalty, as a way to provide new and complementary services to their customers and create a competitive advantage.

\section{Suggestions}

In line with the results of this study, the following suggestions are presented:

- $\quad$ Encouraging customers to submit their comments and suggestions

- $\quad$ Establishing a friendly and lively atmosphere between employees and customers

- $\quad$ Increasing customer-oriented skills of bank employees,

- $\quad$ Spending enough time on listening and solving customer problems,

- $\quad$ Training employees in explaining predictable things to customers

\section{Suggestions for future research}

1. In future studies, researchers should examine the issue from the perspective of continued purchasing and commitment.

2. In future studies, the effect of other variables such as perceived value and customer orientation of employees should be considered.

\section{References}

Auh, S., Bell, S., McLeod, C., \& Shih, E. (2007). Co-production and customer loyalty infi-nancial services.Journal of Retailing, 83(3), 359-370.

Babaei, M.R., Omideh Amini, V., Hassanzadeh, H., \& Chegni, A.R. (2016) Investigating the Impact of Customer Participation on Customer Loyalty with the Mediating Role of Perceived Value

Beerli, A., Martin, J., \& Quintana, A. (2004). A Model of Customer Loyalty in the Retail Banking Market. European Journal of Marketing, 38(1/2), 253-275.

Bendapudi, N., \& Leone, R.P. (2003). Psychological implications of customer participation in coproduction.Journal of Marketing, 67,14-28.

Revilla-Camacho, M. Á., Vega-Vázquez, M., \& Cossío-Silva, F. J. (2015). Customer participation and citizenship behavior effects on turnover intention. Journal of business research, 68(7), 1607-1611.

Chau, V., Ngai, L. (2010). The youth market for internet banking services: perceptions, attitude and behavior. Journal of Services Marketing, 24(1), 42-60.

Chen, Ching-Fu, Jing-Ping Wang (2016) Customer participation, value co-creation and customer loyalty e A case of airline online check-in system, Computers in Human Behavior 62 (2016) 346e352

Chuah, H. W., Marimuthu, M., \& Ramayah, T. (2014). The effect of perceived value on the loyalty of Generation Y mobile internet subscribers: A proposed conceptual framework. Procedia-Social and Behavioral Sciences, 130, 532-541.

Egan, J. (2011). Relationship marketing: exploring relational strategies in marketing (fourth ed). Financial Times/ Prentice Hall.

Grissemann, U.S., \& Stokburger-Sauer, N.E. (2012). Customer Co-Creation of Travel Services: The Role of Company Support and Customer

Satisfaction with the Co-Creation Performance. Tourism Management, 33, 1483-1492.

Hayes, B.E. (2008). The True Test of Loy alty. Quality Pro grass, 41(6):2026

Homburg, C., Grozdanovic, M., \& Klarmann, M. (2007).Responsiveness to customers and competitors: The role of affective and cognitive organizational systems.Journal of Marketing, 71(3), 18-38

Hosseini, M. H., \& Hosseini, V. S. (2013). The impact of co-production on customer loyalty in banking services: A case of Saman Bank.

Hosseinpour, D., Hassan Reza, P. (2011). Relationship between Dimensions...

Hosseinpour, D., Hassan Reza, P. (2011). Research and Technology - Allameh Tabatabai University.

Khabiri, M., Rezgar, M. (2014). A Study of Factors Affecting Customer Participation... 
Manoj, E., Sunil, S. (2011). Role of switching costs in the service quality, perceived value, customer satisfaction and customer retention linkage. Asia Pacific Journal of Marketing and Logistics, 23, 327 $-345$

Meng, SH-M., Liang, G-SH \& Yang, SH-H. (2011). The relationships of cruise image, perceived value,satisfaction, and post-purchase behavioral intention on Taiwanese tourists. African Journal of Business Management, 5(1), 19-29

Morgan, R., Hunt, S. (1994). The commitment-trust theory of relationship marketing. Journal of Marketing, $58(3), 20-38$.

Ndubisi, N.O. (2007). Relationship marketing and customer loyalty. Marketing Intelligence \& Planning, 25, 98-106.

Ou, W-M., Shih, C-M., Chen, C-Y., \& Wang, K-C. (2011). Relationships among customer loyalty programs, service quality relationship quality and loyalty an empirical study. Chinese Management Studies, 5 (2), 194-206

Ou, W-M., Shih, C-M., Chen, C-Y., \& Wang, K-C. (2011). Relationships among customer loyalty programs, service quality relationship quality and loyalty an empirical study. Chinese Management Studies, 5 (2), 194-206.

Paine, J., \&Organ, D. (2000). The culturalmatrix of organizational citizenshipbehavior: Some preliminary conceptual and empirical observations.Human Resource Management Review, 10(1), 45-59.

Rajah E., Marshall R., Nam, I. (2008). Relationship Glue: Customers and Marketers Co-Creating a Purchase Experience. Advances in Consumer Research, 35, 367-373.

Rajah E., Marshall R., Nam, I. (2008). Relationship Glue: Customers and Marketers Co-Creating a Purchase Experience. Advances in Consumer Research, 35, 367-373

Rigatti-Luchini, S.C., Mason, M. (2010). An Empirical Assessment of the Effects of Quality, Value and Customer Satisfaction on Consumer Behavioral Intentions in Food Events. International Journal of Event Management Research, 5(1), 46-61.

Sashi, C. M. (2012). Customer Engagement, Buyer-Seller Relationships, and Social Media. Management Decisions. 50, 253-272.

Selnes, F. (1998). Antecedents and Consequences of Trust and Satisfaction in Buyer-Seller Relationships. European Journal of Marketing, 32, 305-322.

Sharma, S., Conduit, J., \& Hill, S.R. (2014).Organisational capabilities for customer partic-ipation in health care service innovation.Australasian Marketing Journal, 22,179-188

Stan, V., Caemmerer, B., and Cattan-Jallet, R. (2013). Customer Loyalty Development: The Role of Switching Costs. Journal of Applied Business Research, Vol. 29, No. 5, pp. 1541-1554

Tseng, Y.M. (2007). The Impacts of Relationsh ip Mark etin g Tactic s o n Relationsh ip Quality in Serv ic e In dustry. The Busine ss Rev iew, 7(2), 310314.

Vidotto, G., Massidda, D., Noventa, S. \& Vicentini, M. (2012). Trusting Beliefs: A Functional Measurement Study. Psicológica, 33, 575- 590.

Yen, H.R.; Gwinner, K.P. \& Su, W. (2004). The impact of customer participation and service expectation on Locus attributions following service failure. International Journal of Service Industry Management, 15(1), 7-26.

Yi, Y., Nataraajan, R., \& Gong, T. (2011). Customer participation and citizenship behavioral influences on employee performance, satisfaction, commitment, and turnover intention. Journal of Business Research, 64(1), 87-95

Zeithaml, V., Berry, L. and Parasuraman, A. (1996). The behavioral consequences of service quality. Journal of Marketing, 60(2), 31-46. 